\title{
Believability and Feelings in Fake News: A Mind Genomics Cartography
}

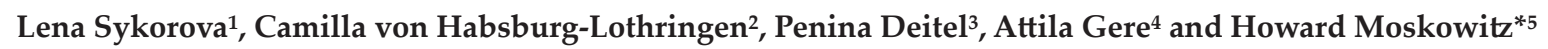 \\ ${ }^{1}$ International Young Leaders Organization, Vienna, Austria \\ ${ }^{2}$ Atmosphärische PR, Vienna, Austria \\ ${ }^{3}$ The Open University, Jerusalem, Israel \\ ${ }^{4}$ Szent Istvan University, Budapest, Hungary \\ ${ }^{5 *}$ Mind Genomics Associates, Inc. New York, USA \& Szent Istvan University, Budapest, Hungary \\ ${ }^{\star}$ Corresponding Author: Dr. Howard Moskowitz, Mind Genomics Associates, Inc. New York, USA \& Szent Istvan University, Budapest, Hungary; Email: mjihrm@gmail. \\ com
}

Received: February 25, 2020; Accepted: March 01, 2020; Published: March 16, 2020;

\begin{abstract}
Respondents evaluated vignettes combining varieties of messages, with the vignettes defined to be aspects of so-called 'fake news.' Each respondent rated a unique set of 24 unique vignettes, systematically varied by an experimental design with the vignettes comprising 2-4 elements. The respondent rated each vignette on a 5-point anchored scale, measuring two factors, feeling (angry vs happy; do not believe vs believe). The data suggest dramatically differences among elements in the degree to which the elements drive both emotion and believability, respectively. Various pairs of mind-sets or different ways of thinking about the information emerged from the clustering of patterns of linkages of elements to emotion, to believability, and to consideration time (response time.) The emergent mind-sets differ on the primary axis of topic (what, how) versus motivation (why.)
\end{abstract}

\section{Introduction}

We depend upon the daily news for a lot of our information, ranging from the weather and what to wear on to the state of our economy, and of course what actions we should take. The common view is that to a great degree the news that we consume, whether from papers or from electronic modes of presentation are 'objective.' That is, we recognize that people may slant the news, but we accept their slanting as 'part of the news itself', recognizing that people have a confirmation bias [1], believing that which agrees with their feeling. When we say that we accept the 'bias,' we mean that we accept bias which is not conscious, but rather part of the 'earnest seekers after truth,' albeit a seeker who must by the human condition have some bias.

The great gift of reporters is that they have the luxury to describe the news after it has happened. It is understood that the reporter will change the story a bit, polishing it to make it attractive for the news consumer to consumer. Polish may be simple, such as better organization of the raw information, out to better, more felicitous but not necessarily 'faithful' reportage of the happened. And, of course, we accept the fact that the news may be presented in a new context. What we think may be a virtue, such as the warm pictures of dictators receiving flowers from children, may actually be horrible in its true context (e.g., agitprop, agitation propaganda [2].

The literature of the news, the reporter, and the emerging world of 'fake news' comes on top of this tradition of respecting the fundamental honesty of the reporter, perhaps at the same time taking into account some of the predilections of the reporter to present information which is not important, but which is perceived to help along a 'story. The topic of Fake News is not new. Fake news, albeit of a strategic nature for war, is well known. One needs only look at the history of espionage, and the 'fake news' fed to the enemy by agents who have been turned. One need not even use a living person. Ewen Montagu's riveting book, The Man Who Never Was provides a detailed account of the WWII effort by the Allies to fool the German High Command about the deployment of troops and material, by outfitting a soldier's body with information, news and plans. The entire effort was an elaborate hoax to fool the German enemy [3].

\section{Issues with fake news}

When a historically so-called objective source of information is polluted by deceit, or perhaps even by mass access of people to create news on social media, one of the results is that the media is no longer believed [4,5] That bold statement may be cause for alarm, but the 'numbers' suggest that fake, or created news, is all around us. For example, according to Allcott \& Gentzkow [6], studying the outcome of the 2016 US election (Trump vs Clinton), “ ... the average American adult saw on the order of one or perhaps several fake news stories in the months around the election, with just over half of those who recalled seeing them believing them; .... people are much more likely to believe stories that favor their preferred candidate, especially if they have ideologically segregated social media network". Furthermore, it Fake News appears almost impossible to stop. Tandoc et. al [5] described the situation in these dire words, focusing on what cannot be done 
anymore." The nature of online news publication has changed, such that traditional fact checking and vetting from potential deception is impossible against the flood arising from content generators, as well as various formats and genres.'

Fake News may be impossible to stop because it is constructed to be inherently interesting, persuasive, and propagandistic. Tandoc et. al. [5] presented a typology of Fake News, using two dimensions of classification, level of factuality, and level of deception. These are not opposites, because within the compass of Fake News are news, satire, news parody, fabrication, manipulation, advertising, and finally propaganda, respectively.

A further aspect of Fake News is the nature of what people want to consume as news. People like their news in different ways. There may be a single definition of what it means to present "NEWS" in a manner consistent with the ethics and morality. Yet, an interview with 61 high school students suggested that the students may prefer opinionated rather than objective news. In Marchi's [7] words 'This does not indicate that young people disregard the basic ideals of professional journalism but, rather, that they desire more authentic renderings of them.'

\section{Fake News, Mind Genomics cartography and process specifics}

The Mind Genomics studies are called cartographies because they 'map' the way a person thinks of a topic. The term 'cartography' is used metaphorically, analogous to mapping human genome. The fundament for Mind Genomics is that every topic relevant to a person in which opinions matter can be studied by a process which reveals the way the person values and responds to information about that topic. The Mind Genomics process cuts the topic into manageable pieces and explores those pieces through experiment. The experiment reveals the specific criteria and weights of the information about the topic, leading to a decision $[8,9]$.

The foregoing definition is general. It is in the specifics that Mind Genomics thinking comes alive. We deal here with aspects of the emerging topic of 'fake news', Our goal is to identify what specific features that we wish to investigate drive a person to 'believe' the news, as well as to feel angry or happy about what is read. It should become immediately obvious that there are a great many cartographic explorations possible for any topic, and that there is no specific, limited, fundamental set of aspects of the topic. We are NOT exploring a limited topic like the set of genes on a chromosome whose number is fixed by biology and nature. Rather, we are using the metaphor of genomics to explore human decision making.

Step 1-Select a topic: The topic may be broad or narrow, naturally occurring or constructed, historic or modern. Our topic is the emerging world of so-called Fake News. We define fake news following one of the more recent classification [5] specifically:

... a typology of types of fake news: news satire, news parody, fabrication, manipulation, advertising, and propaganda. These definitions are based on two dimensions: levels of facticity and deception.

Step 2-Define a set of four questions telling a 'story' about the topic, and for each question provide exactly four alternative answers: The questions and the answers are left to the researcher. Table 1 shows those chosen here. It is important to accept the fact that these questions and answers represent just a sliver of the topic. [Table 1]

Table 1: The four questions and the four answers to each question developed for this first Mind Genomics cartography on Fake News

\begin{tabular}{|c|c|}
\hline & Question A: What is the story about? \\
\hline A1 & reason: politician wants to gain new votes \\
\hline $\mathrm{A} 2$ & reason: politician wants to construct a new power base \\
\hline A3 & reason: public official wants to create approval of policies \\
\hline \multirow[t]{2}{*}{ A4 } & reason: public official wants to disguise problems \\
\hline & Question B: How is the story presented? \\
\hline B1 & story: created with selective false facts \\
\hline $\mathrm{B} 2$ & story: interview constructed by writer \\
\hline B3 & story: expose written to be interesting \& influence feelings \\
\hline \multirow[t]{2}{*}{ B4 } & story: breaking news taken from legitimate sources and "edited" \\
\hline & Question C: What are specific topics? \\
\hline $\mathrm{C} 1$ & topic: public works and infrastructure \\
\hline $\mathrm{C} 2$ & topic: behavior of elected government officials \\
\hline $\mathrm{C} 3$ & $\begin{array}{l}\text { topic: issues in educating young people to question and develop critical } \\
\text { thinking }\end{array}$ \\
\hline \multirow[t]{2}{*}{$\mathrm{C} 4$} & topic: issues negatively affecting quality of life of citizens \\
\hline & Question D: Deliberate distortions \\
\hline D1 & featured: government wrongdoing \\
\hline D2 & featured: putting positive spin on mistakes \\
\hline D3 & featured: explaining away and denying previous history and lessons \\
\hline D4 & featured: overplaying to distract \\
\hline
\end{tabular}

Step 3-Create combinations of answers (so-called vignettes) using experimental design: One of the scientific foundations and thus premised of Mind Genomics research is that the respondents must be presented with the type of information that they would ordinarily encounter, namely mixtures of messages. It is the nature of researchers to isolate variables and test single variables, reducing the other information in order to suppress any noise. The data observed is thus a function of the variable being tested, or in our case the 'answer' being evaluated. The world of Mind Genomics begins with a different premise, namely that in order to understand the mind of the person, it is important to present information in a way that is impossible to 'game,' and 'fake.' When the respondent sees a single element or answer, the respondent can guess about the 'proper rating' to be assigned to that element or answer. Thus, in Table 1, one can present each of the 16 answers or elements, and the respondent may adjust the criteria used in order to be politically correct. 
In the world of Mind Genomics. the researcher uses a main effects experimental design, specially created for this type of study, designed to be efficient, and yet statistically robust. The design comprises 24 vignettes or combinations. Each of the vignettes comprises, by a priori design, a specific set of 2,3 or 4 answers, with only one or no answers from each question.

Another feature of Mind Genomics is the creation of a set of isomorphic or permutated designs, having the same mathematical structure, but comprising different combinations. The result is that each person sees different sets of messages. With such a design, called a 'space-filling design,' the researcher ends up testing a relatively large proportion of the possible combinations [9].

The purist might argue that with permuted designs the measurement of each design is 'noisy', because there is no effort to suppress the noise through replication. The Mind Genomics counter to that argument is that conventional research makes inferences about all possible design combinations from a truly small number of tested combinations, albeit combinations measured accurately because of replication. The difference is one's view of noise versus signal. Mind Genomics accepts more signal (measurement of more combinations), and at the same time, accepts more noise (one replicate judgment per combination.) The world view of Mind Genomics is to measure the space of combinations, accepting the noise, but investigating many regions of the space.

Step 4-Invite respondents to participate by email: During the past two decades consumer researchers have shifted their data collection to the Internet, for reasons of cost and speed. The Internet and the technology empower the researcher to accomplish in the matter of an hour or two what took weeks, perhaps event months. Furthermore, with the competition for people's 'attention' fiercely increasing, it has become obvious that one needs to get 'respondents' from companies who specialize in securing respondents to participate in panels. Without these companies, it is virtually impossible to complete a study with a reasonable number of respondents, and with an interview longer than 30 seconds. The respondents for this study were 'sourced' from Luc.id, a company specializing in providing online consumer panels world-wide.

The respondents received an invitation by email. Most respondents had participated in previous studies hosted by Luc.id (by not necessarily Mind Genomics studies), and readily accepted the email invitation. The respondents were led to the Mind Genomics by means of a link embedded in the email invitation. The response rate was dramatic, with most of the respondents participating within the first 20 minutes, and the entire experiment lasting 90 minutes, in which respondents participated.

Step 5-Instruct the respondents about what they will see: The Mind Genomics program (BimiLeap) presented the respondents with the simple instruction below, and then the five point rating scale. The approach deliberately leaves the task vague, requiring the respondent simply to read the vignette, and assign a rating.
Here are some descriptions of fake news. Please read the description and select how you feel

$1=$ just don't know.

$2=$ don't believe \& feel angry

$3=$ don't believe \& feel happy

$4=$ believe \& feel angry

5=believe \& feel happy

Step 6-Present the respondent with the test stimuli: Present each respondent with 24 different vignettes, comprising combinations of answers, with the combinations comprising two answers, three answers, or four answers, respectively. Each vignette contained at most one answer from each question. The incomplete nature of the vignettes, i.e., vignettes comprising two or three answers instead of four answers, ensured that the answers could be arranged in a socalled 'experimental design,' with the 16 answers or elements being statistically independent of each other. That statistical independence cannot be intuited, but can only be shown by a multivariate statistical analysis (factor analysis).

Each respondent evaluated a unique set of 24 vignettes. The uniqueness was created using a permutation scheme [8]. The 'structure' of the vignettes remained the same, but the particular combinations changed. This feature of individual experimental designs, permutations of one another, empowers the researcher to cover more of the 'design space' of potential combinations, as well as study pairwise and higher order interactions, viz., the effect of one element or answers on the response to another element or answer.

Step 7-Obtain the ratings, transform the ratings to binary using the scheme below, and then create models or equations relating the presence/absence of the elements to the transformed ratings: We write the equation as: Binary Rating or Consideration Time $=\mathrm{k}_{1}(\mathrm{~A} 1)$ $+k_{2}(A 2) \ldots k_{16}(D 4)$. For this study we opted to force the model through the origin, by not incorporating an additive constant. The choice of using an additive constant or not using an additive constant depends upon the interpretation of the additive constant. The constant is useful for simple linear scales, such as $1=$ not interested ... 5=interested. The additive constant is less clear when we combine rating scale points.

Here are the transformations

Consideration: The number of seconds ( 0 to 9 ) between the appearance of the vignette on the respondent's computer or phone screen, and the rating. Time is collected in tenths of a second

Don't believe: Recode 2 and 3 as 100, recode 1,4 and 5 as 0

Believe: $\quad$ Recode 4 and 5 as 100 , recode $1,2,3$ as 0

Angry: $\quad$ Recode 2 and 4 as 100 , recode 1,3 , and 5 as 0

Happy: $\quad$ Recode 3 and 4 as 100 , recode 1,2 , and 4 as 0

Step 8- List the coefficients of the models in a single table: Each column corresponds to one of the dependent variables, and each row corresponding to one of the 16 elements, viz., answers. Table 2 
shows the coefficients for the total panel. In order to find patterns in the results, we sort the table five times, from high to low, once for each dependent variable. We pick up only the strongest elements, as show below. As we see in the lists below, there are a few strong performing elements for each dependent variable. The elements do not necessarily tell a coherent story.

\section{Consideration Time}

B3 story: $\quad$ expose ... written to be interesting \& influence feelings

\section{Angry}

B1 story: created with selective false facts

D3 featured: explaining away and denying previous history and lessons

B4 story: breaking news taken from legitimate sources and "edited"

D1 featured: government wrongdoing
D3 featured: explaining away and denying previous history and lessons

D4 featured: overplaying to distract

\section{Happy}

C3 topic: issues in educating young people to question and develop critical thinking

\section{Don't Believe}

A4 reason: public official wants to disguise problems

A3 reason: public official wants to create approval of policies

Believe

C3 topic: issues in educating young people to question and develop critical thinking

B1 story: created with selective false facts

D1 featured: government wrongdoing

Table 2: Coefficients for the equations relating the presence/absence of the 16 elements to each dependent variable

\begin{tabular}{|c|c|c|c|c|c|c|}
\hline & Total Panel & $\begin{array}{c}\text { Consideration } \\
\text { Time }\end{array}$ & Angry & Happy & Do not believe & Do believe \\
\hline $\mathrm{A} 1$ & reason: politician wants to gain new votes & 1.5 & 12 & 11 & 18 & 4 \\
\hline $\mathrm{A} 2$ & reason: politician wants to construct a new power base & 1.3 & 15 & 9 & 21 & 3 \\
\hline $\mathrm{A} 3$ & reason: public official wants to create approval of policies & 1.7 & 14 & 12 & 21 & 5 \\
\hline A4 & reason: public official wants to disguise problems & 1.4 & 20 & 9 & 22 & 6 \\
\hline B1 & story: created with selective false facts & 1.2 & 31 & 1 & 15 & 17 \\
\hline B2 & story: interview constructed by writer & 1.4 & 17 & 8 & 12 & 13 \\
\hline B3 & story: expose ... written to be interesting \& influence feelings & 1.9 & 16 & 13 & 15 & 14 \\
\hline B4 & story: breaking news taken from legitimate sources and "edited" & 1.7 & 19 & 7 & 14 & 12 \\
\hline $\mathrm{C} 1$ & topic: public works and infrastructure & 1.4 & 13 & 10 & 12 & 11 \\
\hline $\mathrm{C} 2$ & topic: behavior of elected government officials & 1.6 & 13 & 7 & 9 & 11 \\
\hline $\mathrm{C} 3$ & topic: issues in educating young people to question and develop critical thinking & 1.8 & 5 & 18 & 6 & 18 \\
\hline $\mathrm{C} 4$ & topic: issues negatively affecting quality of life of citizens & 1.5 & 16 & 8 & 10 & 14 \\
\hline D1 & featured: government wrongdoing & 1.2 & 23 & 4 & 9 & 17 \\
\hline D2 & featured: putting positive spin on mistakes & 1.4 & 16 & 7 & 16 & 7 \\
\hline D3 & featured: explaining away and denying previous history and lessons & 1.4 & 28 & -3 & 16 & 9 \\
\hline D4 & featured: overplaying to distract & 1.7 & 20 & 4 & 13 & 10 \\
\hline
\end{tabular}

Step 9 - Cluster the respondents based upon the pattern of coefficients, doing so for each of the five key dependent variables, angry, sad, do not believe, belie consideration time, respectively: One of the key contributions of Mind Genomics is the systematized, algorithmic discovery of two, and often three or more 'mind-sets' for each topic. It is obvious that people differ from each other. The typical way to create groups is by WHO THE RESPONSE ARE. A more sophisticated way to divide people does so on the basis of the patterns of self-description, where the topics of self-description are attitudes and behaviors This second clustering is called psychographic clustering because it depends on how the respondent reacts to a fixed set of questions, usually GENERAL questions.

Clustering by who a person IS, or how the person THINKS, are methods that can be relegated to the class of blunt measuring instruments. Although we can do the clustering quite straightforwardly and rigorously either on patterns of classification or patterns of 
responses to general questions about attitudes and behaviors, , it is not clear that the clusters created by using this information (attitudes, behavior) will be of any use to predict how the emergent clusters will react to topic-specific 'micro-questions'. In fact, the reverse is often true. The clusters which emerge from conventional divisions by WHO or HOW ONE THINKS show similar patterns of reactions to a specific topic relevant to the researcher's interest. For example, clusters of people made on the basis of their attitudes towards the general topic of "truth vs misrepresentation" may show a variety of response patterns to information about Fake News.

Mind Genomics clusters respondents based upon the pattern of their individual coefficients, when the coefficients emerge from an investigation of elements deal with a narrow, defined topic, and where the elements paint a 'word picture.' In other words, the clusters emerging from Mind Genomics come from the 'bottom up', from the specifics of a situation. When doing a Mind Genomics study, and clustering the respondents in the foregoing manner, based upon the similarities of the coefficients, it becomes quite straightforward to define the meaning of the clusters, or mind-sets.

The mechanics of clustering are by now well known (Jain \& Dubes,1988.) The fundamentals of clustering are to divide objects (viz., here people) by the differences in certain patterns, with 'difference' defined in various ways. In Mind Genomics one straightforward way, indeed the most frequently used, is to define a 'distance' between two people, based upon the simple index $(1-$ Pearson $\mathrm{R}=$ Pearson Correlation Coefficient.) When two people show a perfectly positive covariation, $\mathrm{R}=,+1$, it means that their patterns are identical. Going one step further in the calculation, we define the distance between these two people as $0(1-1=0)$, which makes sense. When respondents show opposite patterns, the most 'opposite' is a perfectly negative correlation of -1 . The distance is highest, $2(1-1=2)$.

We will do this clustering separately for each of the five dependent variables. The tables will show the differences in the patterns.

\section{Mind-Sets based upon angry (see Table 3)}

MS1 Story: Angry because the story is a fake, information 'spun' and story made-up

B1 story: created with selective false facts

B2 story: interview constructed by writer

B3 story: $\quad$ expose ... written to be interesting \& influence feelings

A2 reason: politician wants to construct a new power base

B4 story: breaking news taken from legitimate sources and "edited"

MS2 Features: Angry because the story has features which make one angry

D3 featured: explaining away and denying previous history and lessons

D1 featured: government wrongdoing
D2 featured: putting positive spin on mistakes

D4 featured: overplaying to distract

Table 3: How the different elements drive the rating of 'angry'

\begin{tabular}{|c|c|c|c|}
\hline & & $\begin{array}{c}\text { Angry } \\
\text { MS1 }\end{array}$ & $\begin{array}{c}\text { Angry } \\
\text { MS2 }\end{array}$ \\
\hline & Base size & 23 & 32 \\
\hline B1 & story: created with selective false facts & 38 & 18 \\
\hline $\mathrm{B} 2$ & story: interview constructed by writer & 33 & -3 \\
\hline B3 & $\begin{array}{l}\text { story: expose } \ldots \text { written to be interesting } \\
\& \text { influence feelings }\end{array}$ & 32 & -1 \\
\hline A2 & $\begin{array}{l}\text { reason: politician wants to construct a } \\
\text { new power base }\end{array}$ & 31 & 8 \\
\hline B4 & $\begin{array}{l}\text { story: breaking news taken from } \\
\text { legitimate sources and "edited" }\end{array}$ & 30 & 7 \\
\hline A4 & $\begin{array}{l}\text { reason: public official wants to disguise } \\
\text { problems }\end{array}$ & 27 & 22 \\
\hline $\mathrm{C} 4$ & $\begin{array}{l}\text { topic: issues negatively affecting quality } \\
\text { of life of citizens }\end{array}$ & 24 & 9 \\
\hline $\mathrm{C} 2$ & $\begin{array}{l}\text { topic: behavior of elected government } \\
\text { officials }\end{array}$ & 21 & 8 \\
\hline A1 & $\begin{array}{l}\text { reason: politician wants to gain new } \\
\text { votes }\end{array}$ & 18 & 13 \\
\hline D3 & $\begin{array}{l}\text { featured: explaining away and denying } \\
\text { previous history and lessons }\end{array}$ & 8 & 51 \\
\hline D1 & featured: government wrongdoing & -1 & 42 \\
\hline D2 & $\begin{array}{l}\text { featured: putting positive spin on } \\
\text { mistakes }\end{array}$ & -14 & 42 \\
\hline D4 & featured: overplaying to distract & 1 & 39 \\
\hline A3 & $\begin{array}{l}\text { reason: public official wants to create } \\
\text { approval of policies }\end{array}$ & 14 & 14 \\
\hline $\mathrm{C} 1$ & topic: public works and infrastructure & 15 & 7 \\
\hline $\mathrm{C} 3$ & $\begin{array}{l}\text { topic: issues in educating young people } \\
\text { to question and develop critical thinking }\end{array}$ & 14 & -2 \\
\hline
\end{tabular}

Mind-Sets based upon happy (Table 4)

MS1-Story topic is interesting and well written, as well as responds positively to the positive efforts by a politician to spin a story:

B3 story: $\quad$ expose ... written to be interesting \& influence feelings

B2 story: interview constructed by writer

B4 story: breaking news taken from legitimate sources and "edited"

A3 reason: public official wants to create approval of policies

A2 reason: politician wants to construct a new power base 


\section{MS2-Story exaggerated to challenge a young person to think, as well as putting a positive spin on mistakes to distract:}

D2 featured: putting positive spin on mistakes

C3 topic: issues in educating young people to question and develop critical thinking

D4 featured: overplaying to distract

Table 4: How the different elements drive the rating of 'happy'

\begin{tabular}{|c|c|c|c|}
\hline & & $\begin{array}{c}\text { Happy } \\
\text { MS1 }\end{array}$ & $\begin{array}{c}\text { Happy } \\
\text { MS2 }\end{array}$ \\
\hline & Base size & 27 & 28 \\
\hline B3 & $\begin{array}{l}\text { story: expose ... written to be interesting \& } \\
\text { influence feelings }\end{array}$ & 31 & -3 \\
\hline B2 & story: interview constructed by writer & 29 & -9 \\
\hline B4 & $\begin{array}{l}\text { story: breaking news taken from legitimate } \\
\text { sources and "edited" }\end{array}$ & 24 & -4 \\
\hline A3 & $\begin{array}{l}\text { reason: public official wants to create } \\
\text { approval of policies }\end{array}$ & 24 & 2 \\
\hline $\mathrm{A} 2$ & $\begin{array}{l}\text { reason: politician wants to construct a new } \\
\text { power base }\end{array}$ & 20 & -6 \\
\hline A4 & $\begin{array}{l}\text { reason: public official wants to disguise } \\
\text { problems }\end{array}$ & 17 & -7 \\
\hline A1 & reason: politician wants to gain new votes & 16 & -2 \\
\hline $\mathrm{D} 2$ & featured: putting positive spin on mistakes & -10 & 26 \\
\hline $\mathrm{C} 3$ & $\begin{array}{l}\text { topic: issues in educating young people to } \\
\text { question and develop critical thinking }\end{array}$ & 16 & 23 \\
\hline D4 & featured: overplaying to distract & -14 & 19 \\
\hline $\mathrm{C} 1$ & topic: public works and infrastructure & 7 & 17 \\
\hline D1 & featured: government wrongdoing & -8 & 15 \\
\hline D3 & $\begin{array}{l}\text { featured: explaining away and denying } \\
\text { previous history and lessons }\end{array}$ & -19 & 13 \\
\hline $\mathrm{C} 4$ & $\begin{array}{l}\text { topic: issues negatively affecting quality of } \\
\text { life of citizens }\end{array}$ & 6 & 11 \\
\hline $\mathrm{C} 2$ & $\begin{array}{l}\text { topic: behavior of elected government } \\
\text { officials }\end{array}$ & 7 & 7 \\
\hline B1 & story: created with selective false facts & 11 & -8 \\
\hline
\end{tabular}

\section{Mind-Sets based on 'Do not believe' (Table 5)}

\section{MS1 -Mistrusts reason for the news, offended by public officials and politicians}

A4 reason: public official wants to disguise problems

A2 reason: politician wants to construct a new power base

A3 reason: public official wants to create approval of policies

A1 reason: politician wants to gain new votes

\section{M2 - Mistrusts stories about government}

D3 featured: explaining away and denying previous history and lessons

D2 featured: putting positive spin on mistakes

D1 featured: government wrongdoing

C3 topic: issues in educating young people to question and develop critical thinking

D4 featured: overplaying to distract

C1 topic: public works and infrastructure

Table 5: How the different elements drive the rating of 'do not believe'

\begin{tabular}{|c|c|c|c|}
\hline & & BelNoS1 & BelNoS2 \\
\hline & Base size & 32 & 23 \\
\hline A4 & $\begin{array}{l}\text { reason: public official wants to disguise } \\
\text { problems }\end{array}$ & 39 & 2 \\
\hline $\mathrm{A} 2$ & $\begin{array}{l}\text { reason: politician wants to construct a new } \\
\text { power base }\end{array}$ & 38 & 1 \\
\hline A3 & $\begin{array}{l}\text { reason: public official wants to create } \\
\text { approval of policies }\end{array}$ & 37 & 11 \\
\hline A1 & reason: politician wants to gain new votes & 34 & -2 \\
\hline D3 & $\begin{array}{l}\text { featured: explaining away and denying } \\
\text { previous history and lessons }\end{array}$ & 2 & 42 \\
\hline D2 & featured: putting positive spin on mistakes & 7 & 36 \\
\hline D1 & featured: government wrongdoing & 3 & 24 \\
\hline $\mathrm{C} 3$ & $\begin{array}{l}\text { topic: issues in educating young people to } \\
\text { question and develop critical thinking }\end{array}$ & -2 & 22 \\
\hline D4 & featured: overplaying to distract & 7 & 21 \\
\hline $\mathrm{C} 1$ & topic: public works and infrastructure & 3 & 20 \\
\hline $\mathrm{C} 2$ & $\begin{array}{l}\text { topic: behavior of elected government } \\
\text { officials }\end{array}$ & 0 & 16 \\
\hline B4 & $\begin{array}{l}\text { story: breaking news taken from legitimate } \\
\text { sources and "edited" }\end{array}$ & 13 & 15 \\
\hline B3 & $\begin{array}{l}\text { story: expose ... written to be interesting \& } \\
\text { influence feelings }\end{array}$ & 12 & 15 \\
\hline $\mathrm{B} 1$ & story: created with selective false facts & 12 & 14 \\
\hline $\mathrm{C} 4$ & $\begin{array}{l}\text { topic: issues negatively affecting quality of } \\
\text { life of citizens }\end{array}$ & 4 & 10 \\
\hline $\mathrm{B} 2$ & story: interview constructed by writer & 10 & 9 \\
\hline
\end{tabular}

\section{Mind-Sets based on 'Believe' (Table 6)}

What people 'believe' is a bit more complex, suggesting one group (MS1) believes stories having certain topics, where the other group (MS) believes stories crafted by politician. It may be that the groups are pointing to the types of fake news to which they have been exposed, or are suggesting that these are type of fake news that they believe are the most salient, within the confines of this Mind Genomics experiment. 


\section{MS1-Believe stories talking government wrongdoing}

C3 topic: issues in educating young people to question and develop critical thinking

D1 featured: government wrongdoing

C2 topic: behavior of elected government officials

D4 featured: overplaying to distract

C1 topic: public works and infrastructure

\section{MS2-Believe stories crafted by politicians}

A4 reason: public official wants to disguise problems

A3 reason: public official wants to create approval of policies

Table 6: How the different elements drive the rating of 'believe'

\begin{tabular}{|c|c|c|c|}
\hline & & BeYesS1 & BelYesS2 \\
\hline & Base size & 32 & 23 \\
\hline $\mathrm{C} 3$ & $\begin{array}{l}\text { topic: issues in educating young people to } \\
\text { question and develop critical thinking }\end{array}$ & 25 & 2 \\
\hline D1 & featured: government wrongdoing & 23 & 8 \\
\hline $\mathrm{C} 2$ & $\begin{array}{l}\text { topic: behavior of elected government } \\
\text { officials }\end{array}$ & 22 & 0 \\
\hline D4 & featured: overplaying to distract & 21 & 1 \\
\hline $\mathrm{C} 1$ & topic: public works and infrastructure & 20 & 2 \\
\hline D3 & $\begin{array}{l}\text { featured: explaining away and denying } \\
\text { previous history and lessons }\end{array}$ & 20 & 1 \\
\hline B1 & story: created with selective false facts & 20 & 7 \\
\hline $\mathrm{C} 4$ & $\begin{array}{l}\text { topic: issues negatively affecting quality of } \\
\text { life of citizens }\end{array}$ & 19 & 16 \\
\hline B3 & $\begin{array}{l}\text { story: expose } \ldots \text { written to be interesting \& } \\
\text { influence feelings }\end{array}$ & 17 & 9 \\
\hline D2 & featured: putting positive spin on mistakes & 16 & -3 \\
\hline B2 & story: interview constructed by writer & 16 & 5 \\
\hline A4 & $\begin{array}{l}\text { reason: public official wants to disguise } \\
\text { problems }\end{array}$ & -9 & 25 \\
\hline A3 & $\begin{array}{l}\text { reason: public official wants to create } \\
\text { approval of policies }\end{array}$ & -16 & 23 \\
\hline A1 & reason: politician wants to gain new votes & -9 & 18 \\
\hline $\mathrm{A} 2$ & $\begin{array}{l}\text { reason: politician wants to construct a new } \\
\text { power base }\end{array}$ & -9 & 18 \\
\hline B4 & $\begin{array}{l}\text { story: breaking news taken from legitimate } \\
\text { sources and "edited" }\end{array}$ & 15 & 10 \\
\hline
\end{tabular}

\section{Mind-Sets based on 'Consideration Time (Table 7)}

Consideration Time (also known as response time or reaction time), may produce new, deeper, and perhaps more fundamental division of respondents The Consideration Time emerges from the 'measurement' of non-conscious processes, specifically the degree to which parts of a message engage., since the clustering is based on upon the pattern of what holds the respondent's attention. Table 7 shows a very strong, and very clear segmentation, based upon the specifics, reason vs what is featured.

Table 7: How the different elements drive the magnitude of 'Consideration Time'

\begin{tabular}{|c|c|c|c|}
\hline & & ConTS1 & ConTS2 \\
\hline & & 24 & 31 \\
\hline A3 & $\begin{array}{l}\text { reason: public official wants to create } \\
\text { approval of policies }\end{array}$ & 2.8 & 0.9 \\
\hline A4 & $\begin{array}{l}\text { reason: public official wants to } \\
\text { disguise problems }\end{array}$ & 2.6 & 0.7 \\
\hline A2 & $\begin{array}{l}\text { reason: politician wants to construct } \\
\text { a new power base }\end{array}$ & 2.5 & 0.4 \\
\hline A1 & $\begin{array}{l}\text { reason: politician wants to gain new } \\
\text { votes }\end{array}$ & 2.3 & 0.9 \\
\hline B3 & $\begin{array}{l}\text { story: expose ... written to be } \\
\text { interesting \& influence feelings }\end{array}$ & 2.1 & 1.7 \\
\hline D4 & featured: overplaying to distract & 0.3 & 2.8 \\
\hline D3 & $\begin{array}{l}\text { featured: explaining away and } \\
\text { denying previous history and lessons }\end{array}$ & 0.2 & 2.4 \\
\hline D1 & featured: government wrongdoing & 0.0 & 2.4 \\
\hline D2 & $\begin{array}{l}\text { featured: putting positive spin on } \\
\text { mistakes }\end{array}$ & 0.3 & 2.3 \\
\hline $\mathrm{C} 3$ & $\begin{array}{l}\text { topic: issues in educating young } \\
\text { people to question and develop } \\
\text { critical thinking }\end{array}$ & 1.7 & 2.0 \\
\hline B4 & $\begin{array}{l}\text { story: breaking news taken from } \\
\text { legitimate sources and "edited" }\end{array}$ & 1.5 & 1.7 \\
\hline $\mathrm{C} 2$ & $\begin{array}{l}\text { topic: behavior of elected } \\
\text { government officials }\end{array}$ & 1.8 & 1.6 \\
\hline $\mathrm{C} 1$ & $\begin{array}{l}\text { topic: public works and } \\
\text { infrastructure }\end{array}$ & 1.7 & 1.5 \\
\hline $\mathrm{C} 4$ & $\begin{array}{l}\text { topic: issues negatively affecting } \\
\text { quality of life of citizens }\end{array}$ & 1.7 & 1.5 \\
\hline $\mathrm{B} 2$ & $\begin{array}{l}\text { story: interview constructed by } \\
\text { writer }\end{array}$ & 1.1 & 1.3 \\
\hline B1 & $\begin{array}{l}\text { story: created with selective false } \\
\text { facts }\end{array}$ & 1.5 & 0.9 \\
\hline
\end{tabular}

\section{MS1 - Clearly engaged by the reason for the news}

reason: public official wants to create approval of policies

reason: public official wants to disguise problems

reason: politician wants to construct a new power base

reason: politician wants to gain new votes

story: $\quad$ expose ... written to be interesting \& influence feelings 


\section{MS2 - Clearly engaged by the topic}

featured: overplaying to distract

featured: explaining away and denying previous history and lessons

featured: government wrongdoing

featured: $\quad$ putting positive spin on mistakes

topic: issues in educating young people to question and develop critical thinking

\section{Discussion}

This paper maps out how people might response to information that they know might the substance of Fake News. Mind Genomics makes it impossible for the respondent to 'game the system, and provide the researcher with appropriate answers. First, no one knows what the appropriate answer is, because of the five responses one can use to rate the vignette, four of the five responses comprise a pair of judgments combined. It is very difficult to game one's response with this structure of responses. Second, the elements incorporated into a single vignette comprise 2-4 different messages. This structure of the stimulus encourages the respondent to give top of the mind answers, rather than trying to be consistent. During the evaluation of 24 vignettes, the memory of one's answer quickly fades, as the respondent copes with each newly created combination. Participating in the experiment is easy when one assigns a 'gut answer' but extremely difficult when one tries to be consistent.

The key findings from this study suggest that Fake News can be deconstructed into different aspects. Beyond the deconstruction into components one requires studies with the person to discover how each aspect functions. The 16 elements studied in this cartography do not, by themselves, show the nature of what type of information drives emotional responses (angry, happy), as well as the type of information that is believed versus not believed. The Mind Genomics effort provides that next layer of data and insight about Fake News.

\section{Acknowledgment}

Attila Gere thanks the support of the Premium Postdoctoral Researcher Program of the Hungarian Academy of Sciences

\section{References}

1. Nickerson RS (1998) Confirmation bias: A ubiquitous phenomenon in many guises. Review of General Psychology 2: 175-220.

2. Kenez ,Peter (1985) The Birth of the Propaganda State: Soviet Methods of Mass Mobilization 1917-1929, Cambridge: Cambridge University Press

3. Montagu E (1953) The Man Who Never was: The Story of Operation Mincemeat. London, Evan

4. Borden SL, Tew C (2007) The role of journalist \& the performance of journalism: Ethical lessons from "fake" news (seriously). Journal of Mass Media Ethics 22 300-314.

5. Tandoc Jr EC, Lim ZW, Ling R (2018). Defining "fake news" A typology of scholarly definitions. Digital Journalism 6: 137-153

6. Allcott H, Gentzkow M (2017) Social media \& fake news in the 2016 election. Journal of Economic Perspectives 31: 211-236.

7. Marchi R (2012) With Facebook, blogs, \& fake news, teens reject journalistic "objectivity". Journal of Communication Inquiry 36: 246-262

8. Moskowitz HR (2012) 'Mind genomics': The experimental inductive science of the ordinary, and its application to aspects of food \& feeding. Physiology \& Behavior 107: 606-613.
9. Moskowitz HR, Gofman A, Beckley J, Ashman H (2006). Founding a new science: Mind Genomics. Journal of Sensory Studies 21; 266-307.
Citation:

Lena Sykorova, Camilla von Habsburg-Lothringen, Penina Deitel, Attila Gere and Howard Moskowitz (2020) Believability and Feelings in Fake News: A Mind Genomics Cartography. Psychol J Res Open Volume 2(2): 1-8. 